\title{
PENGUSADHA DALAM FILSAFAT YOGA DARSANA (Studi Kasus di Desa Payangan, Kecamatan Marga, Kabupaten Tabanan)
}

\author{
I Wayan Titra Gunawijaya \\ STAHN Mpu Kuturan Singaraja
}

\begin{abstract}
Abstrak
Ilmu pengobatan berkembang dengan pesat seiring perkembangan ilmu pengetahuan, meskipun perkembangannya sangat cepat terdapat beberapa hal yang belum dapat dipecahkan dalam dunia medis yaitu penyakit mistik/ non medis. Percaya atau tidak banyak masyarakat mengalami penyakit tersebut yang tidak dapat disembuhkan dalam ilmu pengobatan modern yang kemudian dapat tersembuhkan hanya dengan bantuan obat herbal yang diramu oleh balian/ penekun pengobatan usadha Bali. Dalam proses pengobatannya balian melibatkan energi alam semesta melalui pranayama dan samadhi. Ajaran filsafat yoga asanas dipegang teguh, serta diterapkan dalam proses pengobatan. Untuk mengkaji hal tersebut tentunya akan dilaksanakan penelitian melalui metode kualitatif sebagai dasar pelaksanaan penelitian. Metode pengumpulan data berdasarkan observasi, wawancara, dan metode kepustakaan sebagai pendukung hasil penelitian lapangan, yang kemudian di sajikan dalam bentuk deskrifsi kualitatif.

Pengobatan alternative usadha Bali masih eksis dilaksanakan oleh masyarakat umum terlihat dari antusian masyarakat yang berobat cukup tinggi, begitu juga pemerintah berupaya memfasilitasi Balian diberikan kedudukan di rumah sakit umum untuk melakukan praktek pengobatan. Swadharma seorang balian adalah melakukan pengobatan kepada pasien yang berobat sesuai kode etik balian dalam melakukan pengobatan. Balian berperan sebagai pengobat/ yang mempraktekkan ilmu pengobatan warisan leluhur, sarana yang dipergunakan pun adalah tanaman herbal. Selain itu balian di Bali dalam melakukan pengobatan melakukan kolaborasi dengan filsafat yoga asana khususnya pranayama dan samadhi, kedua hal tersebut menjadi ilmu wajib yang dikuasai oleh balian dalam menekuni ilmu pengobatan.
\end{abstract}

\section{Kata Kunci: Balian, Usadha Bali}

\section{PENDAHULUAN}

Perjalanan hidup manusia tidak pernah terlepas dari bayang-bayang masa lalu, karena pengetahuan akan terus berkembang serta mengalami perubahan seiring penambahan penafsiran serta bukti emperis yang mendukung hal-hal baru. Sehingga tidak menjadi hal mustahil ketika manusia dapat menyentuh ranah teologi/ ilmu ketuhan yang difilsafatkan guna menemukan kebenaran sementara sebelum ditemukan tesis terbaru. Begitu pula dengan perkembangan pengobatan di zaman modern yang begitu pesat, tentunya diimbangi penyakit manusia yang semakin kronis juga. Apakah itu salah ilmu pengetahuan? Beberapa kalangan memandang hal tersebut bisa saja efek negative dari ilmu pengetahuan, secara tidak langsung dapat menemukan senyawa baru dari berbagai persilangan, tentunya berdampak pula kepada kehidupan manusia khususnya dampak Kesehatan.

$$
\text { "Back to natural" menjadi }
$$
dengungan zaman modern untuk mengembalikan sirklus alam semesta yang terkontaminasi oleh aktifitas 
manusia tanpa batas. Kembali mempergunakan bahan-bahan alami untuk menyambung hidup sejatinya menjadi pilihan yang bijak terlepas dari berbagai bahan kimia yang dapat mencekoki sel dalam diri manusia. Maka tidaklah salah leluhur terdahulu mewarisi berbagai ilmu pengeobatan herbal dengan memanfaatkan tanaman yang ada di alam semesta. Kembali membuka lembaran lama akan pengetahuan yang terpendam sejatinya dapat dikomparasikan dengan pengetahuan modern untuk menciptakan kehidupan yang harmonis antar manusia, keselarasan antara manusia dengan alam dan manusia dengan lingkungan sesuai dengan falsafah Hindu (Tri Hita Karana).

Praktisi ilmu pengobatan tradisional banyak membuktikan kepada kalayak umum bahwa eksistensinya masih ada serta dapat membantu penyembuhan orang sakit yang secara medis belum tentu dapat disembuhkan. Sehingga di awal masa jabatannya Gubernur Bali Wayan Koster memastikan Balian Akan Praktik di RS Bersertifikat dengan pertimbangan banyak masyarakat melakukan pengobatan alternative dapat sembuh. Balian vs Dokter ataukan bisa kolaborasi antara Balian dengan dokter akan menjadi problema yang ditimbulkan dari hal tersebut, karena rumah sakit memberikan tawaran pengobatan yang berbeda. Pasilitas yang dipersiapkan pemerintah kemudian apakah sesuai dengan swadharma dari seorang balian apabila telah mengalami komodifikasi. Hal tersebut tertuang dalam swadharma dan swadikara seorang balian sebaga praktisi ilmu pengobatan tradisional (https://news.detik.com/berita/d-

4293905/koster-pastikan-balian-yangakan-praktik-di-rs-bersertifikat)

Melibatan energi alam semesta dalam proses pengobatan alternative yang kemudian dikenal dengan "taksu" sangat dipegang teguh oleh balian 72 sebagai kode etik kedokteran. Ilmu agamapun menjadi pijakan dalam menjalankan taksu tersebut sepertihalnya yoga asana. Proses pengobatan membangkitkan kundalini melalui pembelajaran serta kolaborasi antara pranayama dan samadhi dalam filsafat Yoga sehingga dapat menyamakan prekuensi antara diri dengan alam semesta.

Berbagai penelitian dan buku referensi sudah diterbitkan mengenai ilmu pengobatan alternative/ Usadha Bali sebagai sumber pengetahuan generasi penerus. Kajian-kajian sebagai pembaharuan wajib dilakukan guna upgrade pengetahuan sehingga menjadi lebih baik dan mendekati sempurna. Kajian akan Usadha Bali dalam tataran filsafat Yoga Darsana perlu dilakukan untuk mengetahui kolerasi antara ajaran Hindu di Bali dengan ajaran Filsafat Hindu.

\section{PEMBAHASAN}

\subsection{Pengusadha/ Balian berperan dalam Usadha Bali}

Usada adalah pengetahuan pengobatan tradisional Bali, sebagai sumber konsep untuk memecahkan masalah di bidang kesehatan. Dengan menguasai konsep usada dan memanfaatkannya dalam kerangka konseptual di bidang pencegahan, pengobatan, rehabilitasi serta penelitian berguna untuk mengembangkan ilmu pengetahuan dan teknologi di bidang Kesehatan sebagai alternative pengobatan kepada masyarakat.

Kata usada berasal bahasa Sanskerta yang berarti tumbuhtumbuhan yang mengandung khasiat obat-obatan (Nala, 1992:1). Kata usada ini tidaklah asing bagi masyarakat di Bali, karena usada sering dipergunakan dalam percakapan sehari-hari dalam kaitan dengan mengobati orang sakit. Menurut Sukantra

(1992:124) 
menyatakan usada adalah ilmu pengobatan tradisional. Masyarakat di Bali masih percaya bahwa pengobatan dengan usada banyak maanfaatnya untuk menyembuhkan orang sakit.

Manusia disebut sehat, apabila semua sistem dan unsur pembentuk tubuh (panca maha bhuta) yang berhubungan dengan aksara panca brahma (Sang, Bang, Tang, Ang, Ing) serta cairan tubuhnya berada dalam keadaan seimbang dan dapat berfungsi dengan baik. Sistem tubuh dikendalikan oleh suatu cairan humoral. Cairan humoral ini terdiri dari tiga unsur yang disebut dengan tri dosha (vatta unsur udara, pitta unsur api, dan kapha unsur air). Tiga unsur cairan tri dosha (Unsur udara, unsur api, dan unsur air) dalam pratek pengobatan oleh Balian dan menurut agama Hindu di Bali (Siwasidhanta), Ida Sang Hyang Widhi atau Bhatara Siwa (Tuhan) yang menciptakan semua yang ada di jagad raya ini. Beliau pula yang mengadakan penyakit dan obat.

Dalam beberapa hasil wawancara dengan Balian dan sesuai dengan yang tertera dalam Lontar (Usada Ola Sari, Usada Separa, Usada Sari, Usada Cemeng Sari) disebutkan siapa yang membuat penyakit dan siapa yang dapat menyembuhkannya. Penyakit itu tunggal dengan obatnya, apabila salah cara mengobati akan menjadi penyakit dan apabila benar cara mengobati akan menjadi sembuh (sehat). Secara umum penyakit ada tiga jenis, yakni penyakit panes (panas), nyem (dingin), dan sebaa (panas-dingin) (Nala, 1992:35).

Menyembuhkan suatu penyakit tidaklah cukup hanya ditangani masalah biologinya saja, tetapi harus diketahui juga bhatiniahnya. Masyarakat pada umumnya mencari pertolongan pengobatan bukanlah karena penyakit yang patogen, tetapi kebanyakan akibat adanya kelainan fungsi dari tubuhnya. Masyarakat di Bali masih percaya bahwa pengobatan melalui sisten usada bali bermaanfaat untuk menyembuhkan orang sakit. Walaupun telah banyak ada praktek pengobatan modern di setiap tempat tetapi berobat ke pengobat tradisional Bali (Balian) masih merupakan pilihan yang tidak dapat dikesampingkan begitu saja baik bagi masyarakat Bali.

Pengobatan yang dilakukan oleh Balian di Bali dikenal dengan istilah Tatambaan, dimana Tamba berarti obat (ubad). Dalam prosesi pembuatan obat oleh Balian ada dua hal yang perlu mendapat perhatian yakni serana dan tamba. Tamba adalah segala sesuatu yang dapat dipergunakan untuk menyembuhkan orang sakit, pada umumnya terdiri dari ramuan tumbuhtumbuhan. Sarana adalah merupakan alat penghubung antara kekuatan Balian dengan penyebab penyakit yang ada pada pasien. Obat yang diberikan oleh orang biasa tanpa disertai dengan kekuatan gaib, maka dikatakan bahwa obat itu tanpa serana. Tamba dan serana merupakan satu kesatuan sebagai suatu alat untuk menyembuhkan orang yang sakit. Keduanya saling menunjang agar dapat berfungsi maksimal.

Masyarakat kerap kali mencari alternative pengobatan ke usada Bali selain biaya yang terjangkau jenis penyakit dan juga obat yang diberikan lebih bermujarak dari obat medis. Hal tersebut dikarnakan obat yang diberikan oleh Balian berisi mantra. Kepercayaan masyarakat kepada Balian lebih tinggi dari pada medis meskipun ada beberapa kalangan lebih mengutamakan medis, bahkan menggunakan kedua pengobatan baik medis maupun non medis untuk mendapatkan penyembuhan.

Warga yang mengalami sakit nonmedis jika disentuh langsung oleh sang Balian akan merasa sakit, serta dapat dihilangkan rasa sakitnya dengan seketika hanya dengan meniup bagian sakit tadi, dengan bukti langsung yang diberikan balian katakson-usada di Desa Payangan lebih meningkatkan 
kepercayaan masyarakat kepada Balian katakson-usada. Sistem pembagian penyakit dalam usadha juga dikelompokkan berdasarkan Ayur Weda yang didasarkan atas penyebabnya (Pendit, 2007; 95), meliputi:

1. Adhyatmika, adalah penyakit yang penyebabnya berasal dari dirinya sendiri seperti penyakit keturunan, penyakit kongenital/dalam kandungan, dan ketidakseimbangan pada unsur tri dosha.

2. Adhidaiwika, penyakit yang penyebabnya berasal dari pengaruh lingkungan luar, seperti pengaruh musim, gangguan niskala/supranatural (bebai, gering agung) dan pengaruh sekala.

3. Adhibautika, yaitu penyakit yang disebabkan oleh benda tajam, gigitan binatang, kecelakaan sehingga menimbulkan luka.

Dari ketiga klasifikasi penyakit yang tertuang dalam Ayur Veda, lebih lanjut Jro Mangku Nyoman Dharmayasa, menjelaskan bahwa Balian yang terdapat di Desa Payangan merupakan Balian yang terpelajar yang berdharma sesuai dengan sesana yang tertuang dalam Lontar Bodha Kacapi. Pengobatana yang dilaksanakan oleh Balian di Desa Payangan meningkatkan kesehatan masyarakat. Seorang Balian tidak diperkenankan mematok sesari dalam melakukan pengobatan kepada pasiennya, pengobatan dilaksanakan dengan tulus demi kesembuhan pasien. Dalam melakukan suatu pemeriksaan dan mendiagnosa penyakit, Balian menyimpulkan berdasarkan hasil wawancara, hasil pemeriksaan seperti pemeriksaan fisik seperti melihat aura tubuh, sinar mata, menggunakan kekuatan dasa aksara, chakra, kanda pat dan tenung. Balian kapican, yang menjadi alat pemeriksaan adalah benda bertuah yang diperoleh sebagai pica.

Selain dari pica cara pengobatan oleh seorang Balian adalah 74 dengan menggunakan mantra memohon kepada Sang Hyang Pencipta untuk menyembuhkan segala jenis penyakit yang diderita pasien. System pengobatan juga dijelaskan dalam Lontar Bodha Kacapi, sesuai dengan kutipan berikut: wnang sahananing lara kabeh, maka ngaran hyang sangkul putih, wnang anambanin lara kabeh, hyang tiga padha kasisyanin, ida bhàtara bràhma angadakang gringe kabeh, kasisyanin olih i bhùtha kala dngên, mwang pamala-pamali, mwah ki bhùtha setan, $i$ bhùtha êjim, $i$ bhùtha licin, $i$ bhùtha kakawah, $i$ bhùtha sliwah, $i$ bhùtha ari-ari, $i$ bhùtha rùdhira, $i$ bhùtha êmbaêmba, ika maYoga sami, mangadakang salwiring gring, saking paYogan bhàtara bràhma, marmmaning hana lara kabeh, ring jagat ikang janma. Dadya maYoga ta bhàtara wiûóu, ngawijilang punang tamba, mijil saking sanghyang sùkûma dhana wiúê̂a, saking ungsilan, pita warnnan ida, bhàtara wiûóu iki swaran ida, Ung Ung,

(Lembar 20b; koleksi Fakultas Sastra Universitas Udayanan).

Terjemahan:

Dapat menyembuhkan segala jenis penyakit, ia bernama Hyang Sangkul Putih, bisa mengobati segala penyakit, Hyang Tiga pada menjadi gurunya. Bhatara Brahma mengadakan semua penyakit, dijadikan guru oleh Bhuta Kala Dengen, Pamala-pamali, Ki Bhuta Setan, I Bhuta Jin, I Bhuta Licin, I Bhuta Kakawah, I Bhuta Sliwah, I Bhuta Ariari, I Bhuta Rudira, I Bhuta Emba-emba, mereka semua berYoga menciptakan berbagai penyakit, berkat Yoga Bhatara Brahma sehingga muncul berbagai penyakit di dunia manusia. Lalu Bhatara Wisnu berYoga menciptakan obat, muncul dari Sanghyang Suksmadhana wisesa, dari ginjal, warnanya kuning, dan inilah sabda suci Wisnu: Ung Ung 
bata, úiwan ida sanghyang dhùradha angga, ngaran, mijil ida saking pagantunganing ati, sùkûma dhana wiúeûa, warnnan ida tan patalêtêh, ngaran, swaran ida, Rang, ngaran, sanghyang sùkûma dharmmà wiúêua, mijil ida saking tlênging pupusuh, ngaran, iki swaran ida, Oý, warnnan ida dahat lêwih, kadi damar tan pakukus, ngaran, ika sami sarêng ring paYogan bhàtara wiûou, ngamijilang sarwwa tambà sami. Malih sane dadi gring, iki katatwanya, mwah sane wnang mapagut, ngaran, yan sang bhùtha dngên anggringin, hyang nini úiwàgotra anambanin, waras. Yan i larung masang guóa, hyang три úiwàgaóðu, wnang anambanin, glis waras. Yan ì lêndya apasang guóa, hyang wiûóu pañjaraý makaryya tamba glis waras. Yan $i$ jaran guyang anggringin, hyang jala úangkara anambanin,

(Lembar 21a; koleksi Fakultas Sastra Universitas Udayanan).

Terjemahan:

bata, sebagai junjungan Sanghyang Durada Angga, yang muncul dari penggantungan hati, gaib dan sangat sakti, warnanya jernih tanpa kotoran, sabda sucinya: Rang. Sanghyang Suksma dharma wisesa muncul dari dalam jantung, sabda sucinya: $O \dot{y}$, rupanya sangat indah, bagaikan lampu minyak tanpa asap, mereka sekalian ikut berYoga bersama Bhatara Wisnu, menciptakan segala obat. Ada lagi yang menjadi penyakit, beginilah asalusulnya, dan pula yang dapat menawarnya. Jika sang Bhuta Dengen menimbulkan penyakit, Hyang Nini Siwagotra bertugas mengobati dan sembuh. Jika I Larung memasang gunaguna, Hyang Mpu Siwagandu berhak mengobati, pasti cepat sembuh. Jika I Lendia memasang guna-guna, Hyang
Wisnu Panjaram menciptakan obatnya sehingga lekas

Sistem pengobatan/penatalaksanaan suatu penyakit dalam usadha terdiri atas berbagai pendekatan, meliputi pengobatan tradisional (tamba) seperti loloh, boreh dan minyak/lengis yang didasarkan atas Lontar taru pramana; penggunaan banten-bantenan yang disesuaikan dengan tenung dan Lontar; dan penggunaan rerajahan aksara suci. Secara tidak langsung keberadaan Balian berfungsi sebagai peningkatan sraddha bhakti masyarakat kepada Tuhan Hyang Maha Esa, juga sebagai peningkatan kesehatan atau pengobatan dengan usada. Seorang Balian juga memiliki fungsi sebagai pengharmonis antara manusia dengan Tuhan yang disebut dengan prahyangan di Desa Payangan. Hal tersebut dilandaskan dari penciptaan manusia oleh Ida Sang Hyang Widi Wasa dengan yadnya sehingga sebagai umatnya hendaknya beryadnya sebagai wujud syukur kepada-Nya. Sesuai denga kutipan Bagawadgita III.10, berbunyi sebagai berikut:

Sahayajnah prajah sristwa
pura waca prajapatih anena
prasawisya dhiwan esa
wo'stiwistah kamadhuk

terjemahan:

Pada jaman dahulu Prajapati menciptakan manusia dengan yadnya dan bersabda: dengan ini engkau akan berkembang dan akan menjadi kamadhuk dari keinginanmu (Mantik, 2007; 57).

Dalam kutipan sloka tersebut menjelaskan bahwa manusia terlahir di dunia tidak terlepas dari keinginan yang dipengaruhi oleh sad ripu, segala keinginan umat manusia bersifat sementara. Diperlukan petunjuk pengarah umat dalam menetralisir keinginan yang membelenggu umat manusia. Keberadaan Balian Kataksonusada di Desa Payangan memberikan 
pemahaman kepada masyarakat Desa Payangan mengenai konsep yadnya dan manusia terlahir dari yadnya terbelenggu atas keinginan dengan jalan melaksanakan dharma wacana ataupun dharma tula pada pelaksanaan piodalan dipura setempat.

Ajaran agama Hindu mengajarkan umat Hindu untuk meyakini dan percaya dengan ke-esa-an adanya Tuhan Hyang Maha Esa. Manusia diciptakan oleh Hyang Siwa yang digambarkan seperti Omkara atau Pranava, yakni dada, lengan, kepala dan rambut (ongkara, ardhacandra, vindu, nada), sedang tubuh bagian dalam yakni paru-paru, limpa, jantung, empedu, ati (ongkara, ardhacandra, vindu, maira). Untuk mencapai kelepasan dapat ditempuh dengan enam jalan Yoga yakni pratyahara, dhyana, pranayama, dharana, taka, dan Samadhi (Watra, 2008: 107).

Tingkah laku yang mengikuti Ahangkara memiliki akibat yang disebut karma yang disebut juga Kresna dalam Sloka Bhagavad Gita VIII.3 sebagai berikut:

\section{Aksaram brahma paramam svabhavo dhyatmam ucyate Bhuta-bhavodbhava-karo visargah karma-samjnitah}

Terjemahan:

Brahman atau yang mutlak adalah tidak bias dihancurkan, yang maha tinggi (lebih tinggi daripada apapun), sifat ini dikatakan sebagai atman, karma adalah nama yang diberikan kepada kekuatan kreatif yang membawa mahluk ke dalam keberadaanya (Mantik, 2007;147).

Tentang pelepasan manusia dari karma, dalam Sloka VIII. 5 Bhagavad Gita, Kresna mengatakan:

Anta-kale ca mam eva

Smaram muktva kalevaram

Yah prayati sa mad-bhavam

Yuti nasty atra samsayah
Terjemahan:

Dan siapa saja, ketika ajal datang, melepaskan raganya dan melakukan perjalanan, dan memikirkan aku saja, dia akan datang dalam kedudukan-Ku, mengenai hal ini tidak ada keraguan (Mantik, 2007;149).

Pencapaian sifat Yang Maha Kuasa atau moksa dapat terlaksana jika seluruh karma telah hilang. Pada saat itu seluruh diri manusia hanya ingat kepada Brahman, lepas pada pikiran tentang yang lain. Moksa merupakan pembebasan dalam kaitannya dengan keabadian. Pencarian keabadian yang dilakukan manusia secara serius dan bersungguh-sungguh akan berujung pada moksa.

Keberadaan Balian khususnya di Desa Payangan tidak pernah terlepas dari segi negatif. Dari berbagai fungsi Balian telah dipaparkan diatas, Balian Katakson-usada di Desa Payangan ternyata memiliki fungsi negatif yaitu memecah belah persatuan dalam kekeluargaan. I Nyoman Sisa Margawan menjelaskan bahwa beberapa warga yang datang ke Balian menghasilkan perpecahan dalam keluarganya, hal tersebut disebabkan karena keluarga yang sakit datang ke Balian Kataksonusada, dalam proses pengobatannya sang Balian Katakson-usada menyatakan bahwa tiada lain orang yang membuat sakit adalah salah satu keluarganya, karena salah satu keluarganya tersebut dituduh telah mempelajari ilmu Leak. Dari fenomena tersebut jelas akan menimbulakan perpecahan dalam keluarga karena telah terjadi kecuriagaan antara anggota keluarga. Dalam kehidupan social di masyarakat sering terkena cetik, atau racun berbahaya yang disebabkan oleh ilmu gaib. Orang yang terkena cetik di warung makan, sesungguhnya yang memberi cetik itu bukan pemilik warung melainkan orang lain. Ketika berobat ke Balian, sesuai dengan etikanya tidak diperkenankan membongkar rahasia 
orang yang tertuga menyebarkan penyakit. Tentunya hal ini meminimal terjadinya kesalah pahaman antara warga satu dengan yang lainnya.

\subsection{Filsafat Yoga Darsana dalam proses Usadha Bali \\ 1. Pranayama}

Pranayama merupakan ilmu tentang cara pengendalian nafas melalui pengaliran prana. Dengan demikian mampu membawa pikiran dalam keadaan tenang (laghawa) dan mudah untuk berkonsentrasi. Kondisi nafas dalam kehidupan secara normal yaitu puraka (nafas masuk), rechaka (nafas keluar) dan kumbhaka (penahanan nafas dia antara dua geraka di atas). Napas yang dipimpin oleh pikiran, merupakan tenaga yang kuat dalam menghidupkan kembali sel-sel tubuh, yang digunakan untuk pengembangan diri sehingga mampu mengatasi berbagai penyakit dan dengan pranayama maka nadi-nadi akan menjadi bersih sehingga mampu membantu bangkitnya kundalini.

Dalam ajaran Yoga Asanas terdapat beberapa jenis pranayama yaitu adhama, madyama dan uttama (yang rendah, sedang, atau yang paling tinggi). Adhama pranayama terdiri dari 12 matra, madhyama terdiri dari 24 matra dan uttama menyita waktu 32 matra. Sedangkan kumbhaka merupakan penyimpanan atau penahanan nafas, yang dapat meningkatkan periode kehidupan. Memperbesar kekuatan bathin, keberanian dan vitalitas. Yogi dengan penarikan nafas pada brahmarandhradi puncak kepala dan dengan menjaganya tetap disana, mampu mengalahkan dewa kematian Yama, dan dapat menaklukan kematian. (Wibawa, 1998: 59). Kekuatan pranayama sangat luar biasa apabila dapat diaplikasikan dengan baik, benar, dan tepat.

Jro mangku Nyoman Dharmayasa mengatakan olah nafas terdiri dari berbagai jenis, yang lebih lanjut diterangkan dalam Yoga Kundalini sebagai contoh, Tutup lobang hidung kanan dengan jempol tangan kanan. Menghisap napas (Purvak) melalui lobang hidung kiri perlahan-lahan dengan menghitung 3 kali OM (OM, $\mathrm{OM}, \mathrm{OM}$ ). Mengan memperdalam pranayama akan meningkatkan kekebalan diri seorang Balian. Pranayama merupakan pokok seorang Balian khususnya Balian Kataksonusada dalam upaya mengobati pasien.

Lebih lanjut Jro Mangku Nyoman Dharmayasa yang juga merupakan Balian Katakson-usada memaparkan sebelum melakukan pengobatan kepada orang lain setelah duduk di gedong/tempat pengobatan melaksanakan pengaturan nafas terlebih dahulu untuk membangkitkan kundalini sehingga besik Balian lebih kuat dan tidak juga terlepas dari tuntunan betara hyang guru.

Mengenai pranayama juga dipaparkan dalam sloka Bhagavad Gita IV sloka 27, sebagai berikut:

Sarvanindriya-karmani

prana-karmani capare

Atma-samyama-Yogagnau juhvati jnana dipite

Terjemahan:

yang lainnya lagi mempersembahkan semua fungsi dari indriya-indriyanya dan perbuatan dari nafas kehidupannya (prana-nya) ke dalam Yoga dari pengendalian diri yang diberi cahaya oleh pengetahuan sejati (Mantik, 2007; 90).

Dari kutipan Kitab Suci Bhagavad Gita tersebut dinyatakan bahwa kebesaran pranayaman adalah penting guna memperoleh sinar suci pengetahuan, sehingga seorang Balian Katakson-usada melakukan pranayama untuk memperoleh sinar suci pengetahuan dari Ida Sang Hyang Widhi Wasa.

\section{Samadhi}


Samadhi merupakan keadaan supra sadar yang didapatkan melalui proses pemusatan pikiran yang sangat kuat dan mendalam, terbebas dari sangkalpa dan keterikatan duniawi sehingga mencapai mukti dan penyerahan diri sepenuhnya jiwa dengan Paramatma. Tujuan tertinggi dari keseluruhan sistem Yoga adalah keterpisahan mutlak antara purusa dan prakrti, yaitu tercapainya kaiwalya atau kemerdekaan mutlak. Bebasnya purusa kedalam wujud yang sebenarnya (swarupa) tidak lagi bergantung pada apapun didunia ini.

Jro Mangku Nyoman Dharmayasa menjelaskan bahwa Balian Kataksonusada merupakan sebuah kedidikan suci yang telah ditingkatkan tarap hidupnya dengan melaksanakan upacara pawintenan Balian di sanggah merajan. Dengan demikian secara tidak langsung Balian telah memiliki surat rekomendasi untuk mengadakan komunikasi dengan betara hyang guru melalu taksnunya. Semadhi merupakan pemusatan pikiran tertinggi yang dilaksanakan oleh Balian Katakson-usada dengan kemungkinan memulihkan kondisi yang telah turun karena mengobati pasien ataupu meningkatkan pengentahuan suci, dan menenangkan gelombang pikiran sehingga dapat menyatu dengan alam (bhuana agung).

$$
\text { Lebih lanjut Jro Mangku }
$$

Nyoman Dharmayasa menjelaskan bahwa Yoga memiliki perananan sangat penting dalam menunjang Balian Katakson-usada baik dalam proses pendapatan ilmu ataupun pengendalian diri sehingga tidak terlepas dari swadharma seorang Balian. Selain itu Yoga merupakan bagian dari sad darsana yang menjadi pokok dasar yang harus dikuasai sebelum menjadi seorang Balian yang termuat dalam Sastra Sanga.

Sad Darsana merupakan pengetahuan wajib yang harus dikuasai oleh seorang Balian Katakson-usada selain pengetahuan yang terdapat dalam sastra sangga. Bagian paling dominan 78 dilaksanakan oleh Balian KataksonUsada dari bagian Sad Darsana adalah Yoga, sesuai penjelasan diatas, dalam kehidupan bermasyarakat di Desa Payangan Balian Katakson-Usada juga menganut paham Mimamsa yaitu dalam pelaksanaan pengobatan terdapat ritual yang terselip sebagai sarana pengobatan, baik dalam pawintenan sebelum menjadi Balian Katakson-Usada atau upacara pengluakatan warga yang menderita sakit.

Dalam pembahsan Mimamsa terkait dalam ritual adanya sarana yang dipakai, seperti banten penglukatan serta daksina yang dipergunakan sebagai pengganti jasa Balian Ketakson-usada. Sekilas terjemahan lontar budha kecapi memaparkan bahwa seorang balian tidak diperkenankan untuk menerima upah atau imbalan melebihi standar daksina. Dimana di dalam daksina tersebut sudah ada beras, kelapa, telur dan sesari uang kepeng, akan tetapi seiring perkembangan zaman modern Balian ternyata juga mengalami komodifiksi terkait kepada penggunaan sesari. I Wayan Budiasa dalam pernyataannya menyebutkan sebagai berikut:

Zaman dulu berbicara masalah balian cukup hanya membawa canang sari berisi sesari ya maksimal 10.000 rupiah, tapi dizaman modern sekarang hal tersebut mengalami perkembangan canang sari berganti menjadi pejati yang berisikan daksina dan berbagai perlengkapan lainnya dan berisi sesari lebih dari 50.000 rupiah. Jadi nilai balian sekarang berkembang juga. Selain itu pelaksanaan ritual pengobatan bisa praktis karena telah disiapkan di jro (rumah Balian), seperti banten penglukatan lengkap dengan ayam yang telah di panggang.

Dari kutipan wawancara tersebut sekilas dijelaskan bahwa balian di desa payangan juga mengalami perkembangan baik dari imbalan yang diperoleh oleh seorang balian, seperti daksina dari sesari uang kepeng 
berkembang menjadi uang dengan nilai tinggi. Dan selanjutnya jro atau rumah balian juga mengalami komudifikasi di bidang bebantenan. Dimana staf balian menjual banten kepada pasien yang dipergunakan untuk melukat atau pembersihan pisik si pasien.

Hal tersebut dikarenakan kebutuhan hidup semakin banyak serta tidak bisa menjalankan kehidupan hanya dengan imbalan daksina yang dibawa oleh pasien sehingga terjadi gebrakangebrakan baru baik pembuatan banten dan sesari, selain itu biasanya pasien bernegosiasi dengan balian dengan mengatakan berani membayar berapa saja kepada balian jika pasien dapat disembuhkan. Dengan demikian balian ketakson-usada juga mengalami perkembangan ekonomi dalam ritual dalam konsep mimamsa darsana. .

\section{SIMPULAN}

Pengobatan alternative usadha Bali masih eksis dilaksanakan oleh masyarakat umum terlihat dari antusian masyarakat yang berobat cukup tinggi, begitu juga pemerintah berupaya memfasilitasi Balian diberikan kedudukan di rumah sakit umum untuk melakukan praktek pengobatan. Swadharma seorang balian adalah melakukan pengobatan kepada pasien yang berobat sesuai kode etik balian dalam melakukan pengobatan. Balian berperan sebagai pengobat/ yang mempraktekkan ilmu pengobatan warisan leluhur, sarana yang dipergunakan pun adalah tanaman herbal. Selain itu balian di Bali dalam melakukan pengobatan melakukan kolaborasi dengan filsafat yoga asana khususnya pranayama dan samadhi, kedua hal tersebut menjadi ilmu wajib yang dikuasai oleh balian dalam menekuni ilmu pengobatan.

\section{DAFTAR PUSTAKA}

Bajera. 2008. Tesisnya berjudul "Balian Usada dikabupaten Gianyar (perspektif Hindu)".

Donder, I Ketut. 2006. Brahmavidya: Theologi Alam Semesta. Surabaya : Paramita.

Koentjaraningrat. 1981. Kebudayaan dan Mentalitet Pembangunan. Jakarta: Gramedia.

Nala, Ngurah, 2006.Aksara Bali Dalam Usadha, Surabaya; Paramitha.

Nala, Ngurah, 1992.Usadha Bali, Denpasar; Upada Sastra.

Prabhupada, Bhaktivedanta Swami, 1986. Bhagavad Gita Sesuai Dengan Aslinya, Jakarta. Hanuman Sakti.

Subagiasta, I Ketut. 2007. Susastra Hindu. Surabaya: Paramita.

Supatra, I Nyoman, 2005.Ki Balian Batur Guru Aji Pengiwa, Denpasar: CV Bali Media.

Titib, I Md. 2003. Purana Sumber Ajaran Agama Hindu Komprehensif. Jakarta : Pustaka Mitra Jaya.

Yendra, I Wayan. 2008. I Balian Putus Mengobati Tanpa Obat Menyembuhkan Tanpa Kambuh. Surabaya: Paramita. 